Abstracta Iranica Abstracta Iranica

Revue bibliographique pour le domaine irano-aryen

Volume 30 | 2010

Comptes rendus des publications de 2007

\title{
«Constructing a legal case against Iran's nuclear right to enrich within the International Court of Justice ». Al Nakhlah, printemps 2007, pp. 30-40.
}

\section{Anicée Van Engeland}

\section{(2) OpenEdition}

1 Journals

Édition électronique

URL : http://journals.openedition.org/abstractairanica/38133

DOI : 10.4000/abstractairanica.38133

ISSN : 1961-960X

Éditeur :

CNRS (UMR 7528 Mondes iraniens et indiens), Éditions de l'IFRI

Édition imprimée

Date de publication : 8 avril 2010

ISSN : 0240-8910

Référence électronique

Anicée Van Engeland, « «Constructing a legal case against Iran's nuclear right to enrich within the International Court of Justice ». Al Nakhlah, printemps 2007, pp. 30-40. », Abstracta Iranica [En ligne], Volume 30 | 2010, document 316, mis en ligne le 08 avril 2010, consulté le 29 septembre 2020. URL http://journals.openedition.org/abstractairanica/38133; DOI : https://doi.org/10.4000/ abstractairanica.38133

Ce document a été généré automatiquement le 29 septembre 2020.

Tous droits réservés 
« Constructing a legal case against Iran's nuclear right to enrich within the International Court of Justice ». Al Nakhlah, printemps 2007, pp. 30-40.

\section{Anicée Van Engeland}

1 L'originalité de cet article réside dans l'effort de construire un argument juridique pour réfuter le droit de l'Iran de se développer en puissance nucléaire. Ce scénario factice prend pour témoin la Cour Internationale de Justice récemment créée. En s'appuyant sur diverses conventions internationales dont le traité de la non-prolifération nucléaire, l'A. démontre qu'il y a une limite à l'enrichissement nucléaire. Il met en parallèle le développement nucléaire brésilien et iranien avant de conclure en faveur d'un arbitrage par la Cour.

INDEX

Thèmes : 13.1. Iran 
AUTEURS

ANICÉE VAN ENGELAND

European University Institute - Florence 